\title{
ОСОБЛИВОСТІ БУХГАЛТЕРСЬКОГО ОБЛІКУ В НЕПРИБУТКОВИХ ОРГАНІЗАЦІЯХ
}

\author{
Кірдіна О.Г., д.е.н., професор, \\ Кудрявець Н.В., студентка (УкрДУЗТ)
}

\begin{abstract}
Неприбуткова організаиія - ие самостійний суб'єкт господарювання правами юридичної особи, який здійснюе діяльність згідно установчих документів, має самостійний баланс, поточні рахунки в банках, печатку, веде бухгалтерський облік, подає звітність згідно із законодавством, не має на меті отримання прибутку. Визначення доходів та витрат неприбуткових організаиій з метою оподаткування здійснюється на підставі ПБО та даних бухгалтерського обліку. Всі неприбуткові організації (як підприємнищького характеру, так $i$ ті, щзо не мають заборони на підприємницьку діяльність) об'єднані одним принщипом: доходи, отримані в межах своєї статутної діяльності, використовуються винятково для фінансування видатків на утримання такої організації, реалізачії мети (цілей, завдань) та напрямів діяльності, визначених ї̈ статутними документами.
\end{abstract}

Ключові слова: неприбуткова організація, бухгалтерський облік, оподаткування, доходи, видатки.

\section{ОСОБЕННОСТИ БУХГАЛТЕРСКОГО УЧЕТА В НЕПРИБЫЛЬНЫХ ОРГАНИЗАЦЯИХ}

\author{
Кирдина Е.Г., д.э.н., профессор, \\ Кудрявец Н.В., студентка (УкрГУЖТ)
}

Неприбыльная организащия - это самостоятельный субъект хозяйствования $c$ правами юридического лииа, осуществляющий деятельность согласно учредительных документов, который имеет самостоятельный баланс, текущие счета в банках, печать, ведет бухгалтерский учет, подает отчетность согласно законодательству, не имеет иелью получения прибыли. Определение доходов и расходов неприбыльных организаций с целью налогообложения осуществляется на основании ПБУ и данных бухгалтерского учета. Все неприбыльные организачии объединены одним принципом: доходы, полученные в ралках своей уставной деятельности, используются исключительно для финансирования расходов на содержание такой организации, реализации цели (челей, задач) и направлений деятельности, определенных ее уставными документами.

Ключевые слова: неприбыльная организация, Бухгалтерский учет, налогообложение, доходы, расходы.

\section{PECULIARITIES OF ACCOUNTING IN NON-PROFIT ORGANIZATIONS}

\author{
Kirdina E.G., doctor of Economics, Professor, \\ Kudryavets N.V., magistr (USURT)
}

A non-profit organization is an independent business entity under the rights of a legal entity that operates under the constituent documents, has an independent balance sheet,

(C) Кірдіна О.Г.,

Кудрявець Н.В.

Вісник економіки транспорту і промисловості № 65, 2019 
current accounts in banks, a seal, maintains accounting records, submits reports under the law, does not have the purpose of making a profit. Determination of income and expenses of non-profit organizations for tax purposes is carried out on the basis of PBU and accounting data. All non-profit organizations (both of an entrepreneurial nature, and those that do not have a ban on entrepreneurial activity) are United by one principle: the income received within the framework of its statutory activities is used exclusively to Finance the costs of maintaining such an organization, the realization of the goal (goals, objectives) and activities defined by its statutory documents.

Analysis of accounting features of non-profit organizations allowed to identify the main problems they face during the implementation of their own activities: lack of staff, lack of manuals for accounting and financial reporting; lack of special software for accounting in non-profit organizations. Their decision is assigned to the following actions: to prepare at the legislative level projects that simplify the provision of annual reports of non-profit organizations; to implement projects providing consulting assistance on accounting standards in non-profit organizations; to develop common rules for accounting and financial reporting in non-profit organizations.

Key words: non-profit organization, Accounting, taxation, income, expenses.

Постановка проблеми та іï зв'язок з науковими чи практичними завданнями. Для сучасного етапу розвитку суспільства у глобальних умовах характерними $\epsilon$ типові проблеми щодо зростання рівня бідності, значної диференціації доходів населення, збільшення кількості економічно депресивних регіонів, низької ефективності владних інституцій.

Вирішення означених проблем значною мірою покладено на прийняття грамотних управлінських рішень у сфері соціального захисту населення. Проте, слід відзначити, що спостерігається стійка тенденція делегування виконання соціальних функцій громадським організаціям, які за особливостями своєї діяльності $\epsilon$ неприбутковими. Саме неприбуткові громадські організації займаються забезпеченням соціальної справедливості, наданням можливостей для самореалізації особистості, формуванням якісних і загальнодоступних систем освіти, охорони здоров'я та соціального захисту.

Історично обумовлено, що розвиток неприбуткових організацій відбувається під впливом економічних умов і національних традицій. Наявність різноманітних підходів до організації функціонування організацій вимагає дослідження особливостей їх бухгалтерського обліку й оподаткування.

Аналіз досліджень і публікацій останніх років. На превеликий жаль, питання щодо ведення бухгалтерського обліку й оподаткування діяльності неприбуткових організацій не знайшли достатнього відображення в українській науці. Нечисленні праці, які стосуються означеної проблематики, у більшому ступені розкривають практичні підходи до ведення бухгалтерського обліку неприбуткових організацій. Зокрема, у цій царині слід виокремити роботи Слободяник Ю.Б. [3], Пантейлічук С.Л. [4], Габрук О., Пантелійчук Л. [8], Папінової О. [9], Тарасової М. [10] та ін. Окремі аспекти діяльності неприбуткових організацій розкрито у працях В. Диканя, С. Панченко, Ю. Уткіної, І. Воловельскої, В. Маслової, О. Полякової, О Шраменко [5-7] та ін.

Виділення невирішених раніше частин загальної проблеми. Однак, незважаючи на отримані результати, подальші дослідження питань щодо організації бухгалтерського обліку й оподаткування неприбуткових організацій залишаються недостатньо дослідженими. 
Формування цілей статті. Саме тому метою статті $\epsilon$ дослідження особливостей бухгалтерського обліку й оподаткування у неприбуткових організацій.

Виклад основного матеріалу дослідження. Поняття «неприбуткова організація» закріплено Податковим Кодексом України [1]. До внесення змін у Податковий кодекс неприбуткові підприємства, установи та організації визначалися як підприємства, установи та організації, основною метою діяльності яких $\epsilon$ не одержання прибутку, а провадження благодійної діяльності та меценатства і іншої діяльності, передбаченої законодавством. Законом №652 від 17.07.2015 [2] дане поняття було викладено в новій редакції. Згідно пп.14.1.121 Податкового Кодексу неприбуткові підприємства, установи та організації - це ті юридичні особи, які не $\epsilon$ платниками податку на прибуток підприємств у відповідності 3 п. 133.4 ПКУ [1].

Пп. 133.4.1 Податкового кодексу [1] визначено вимоги до організації для отримання статусу неприбутковості:

- утворено та зареєстровано в порядку, визначеному законом, що регулює діяльність відповідної неприбуткової організації;

- установчі документи якої містять заборону розподілу отриманих доходів (прибутку) або їх частки серед засновників (учасників), членів організації, працівників (крім оплати їх праці, нарахування єдиного соціального внеску), членів органів управління та інших пов'язаних з ними осіб;

- установчі документи якої передбачають передачу активів одній або кільком неприбутковим організаціям відповідного виду або зарахування у дохід бюджету в разі припинення юридичної особи в результаті ii ліквідації, злиття, поділу, приєднання або перетворення);

- внесена контролюючим органом до Реєстру неприбуткових установ та організацій.

I найголовніше, згідно з пп. 133.4.2:

доходи (прибуток) неприбуткової організації повинні використовуватися виключно для фінансування витрат на утримання такої неприбуткової організації, реалізації мети (цілей, завдань i напрямів діяльності, визначених іiі установчими документами [1].

Основна відмінність

від прибуткових (комерційних) організацій: комерційна організація створюється виключно заради отримання прибутку і $є$ платником податку на прибуток, a неприбуткова - мети отримання матеріальної вигоди не переслідує. Некомерційна організація в основному грунтується для формування сприятливих умов життя людей і досягнення суспільно значущих соціальних благ.

Неприбуткові організації в Україні класифікуються наступним чином (табл. 1).

3 точки зору бухгалтерського обліку, відмінності між неприбутковими організаціями та комерційними підприємствами полягають у відсутності процесів виробництва та реалізації продукції (послуг), отриманні значної частини доходів у вигляді цільового фінансування від членів та нечленів організації, відсутності статутного капіталу в більшості, а також і поставок товарів (робіт, послуг) 3 основної діяльності, тобто об'єкта оподаткування ПДВ.

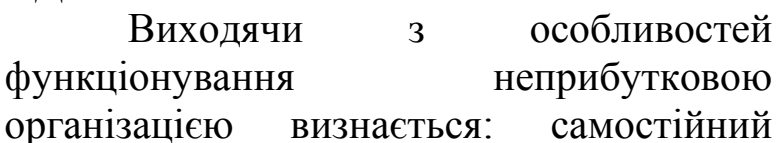
суб'єкт господарювання за правами юридичної особи, який здійснює діяльність згідно установчих документів, має самостійний баланс, поточні рахунки в банках, печатку, веде бухгалтерський облік, подає звітність згідно із законодавством, не має на меті отримання прибутку. 
Класифікаиія неприбуткових організацій [3]

\begin{tabular}{|c|c|c|c|}
\hline Найменування суб’єкта & Код & Найменування суб'єкта & Код \\
\hline Органи державної влади & 0001 & Пенсійні фонди & 0009 \\
\hline $\begin{array}{c}\text { Установи, організації, створені } \\
\text { органами державної влади України, } \\
\text { що утримуються за рахунок коштів } \\
\text { відповідних бюджетів }\end{array}$ & 0002 & Кредитні спілки & 0010 \\
\hline Органи місцевого самоврядування & 003 & $\begin{array}{c}\text { Інші юридичні особи, діяльність яких } \\
\text { не передбачає отримання прибутку }\end{array}$ & 0011 \\
\hline $\begin{array}{c}\text { Установи, організації, створені } \\
\text { органами місцевого самоврядування, } \\
\text { що утримуються за рахунок коштів } \\
\text { відповідних бюджетів }\end{array}$ & 0004 & $\begin{array}{c}\text { Спілки, асоціації та інші об'єднання } \\
\text { юридичних осіб, створені для } \\
\text { представлення інтересів засновників } \\
\text { (членів, учасників), що утримуються } \\
\text { лише за рахунок внесків таких } \\
\text { засновників (членів, учасників) та не } \\
\text { провадять господарської діяльності, } \\
\text { за винятком отримання пасивних } \\
\text { доходів }\end{array}$ & 0012 \\
\hline $\begin{array}{c}\text { Благодійні фонди (організації), } \\
\text { створені в порядку, визначеному } \\
\text { законом для здійснення благодійної } \\
\text { діяльності }\end{array}$ & 0005 & Релігійні організації & 0013 \\
\hline $\begin{array}{c}\text { Громадські організації, створені з } \\
\text { метою надання реабілітаційних, } \\
\text { фізкультурно-спортивних та } \\
\text { соціальних послуг для інвалідів (дітей- } \\
\text { інвалідів), правової допомоги, } \\
\text { провадження екологічної, оздоровчої, } \\
\text { аматорської спортивної, культурної, } \\
\text { просвітньої, освітньої та наукової } \\
\text { діяльності, громадські організації } \\
\text { інвалідів, спілки громадських } \\
\text { організацій інвалідів та їх місцеві } \\
\text { осередки, створені згідно з законом }\end{array}$ & 0006 & $\begin{array}{c}\text { Науково-дослідні установи та вищі } \\
\text { навчальні заклади III-IV рівнів } \\
\text { акредитації, внесені до Державного } \\
\text { реєстру наукових установ, яким } \\
\text { надається підтримка держави, } \\
\text { заповідники, музеї-заповідники }\end{array}$ & 0014 \\
\hline Творчі спілки & 0007 & $\begin{array}{c}\text { Житлово-будівельні кооперативи та } \\
\text { об'єднання співвласників } \\
\text { багатоквартирних будинків }\end{array}$ & 0015 \\
\hline Політичні партії & 0008 & $\begin{array}{c}\text { Професійні спілки, їх об'єднання та } \\
\text { організації профспілок, а також } \\
\text { організації роботодавців та їх } \\
\text { об'єднання, утворені в порядку, } \\
\text { визначеному законом }\end{array}$ & 0016 \\
\hline
\end{tabular}

На сьогодні немає спеціального Нормативу (стандарту) бухгалтерського обліку для неприбуткових організацій, тому на даному етапі неприбуткові організації застосовують при веденні бухгалтерського обліку всі діючі П(С)БО. Неприбуткові організації мають такі особливості діяльності, які відрізняють їх 3-поміж інших комерційних структур [4]. Законом про оподаткування прибутку регламентуються види доходів, які звільняються від оподаткування для кожної такої організації.

До таких доходів, зокрема, відносяться: надходження цільового характеру; внески засновників; безкоштовне отримання товарноматеріальних цінностей i коштів від фізичних та юридичних осіб; надходження від здійснення операцій, передбачених установчими документами; доходи від здійснення операцій з цінними паперами, депозитними вкладами та інші пасивні доходи. 


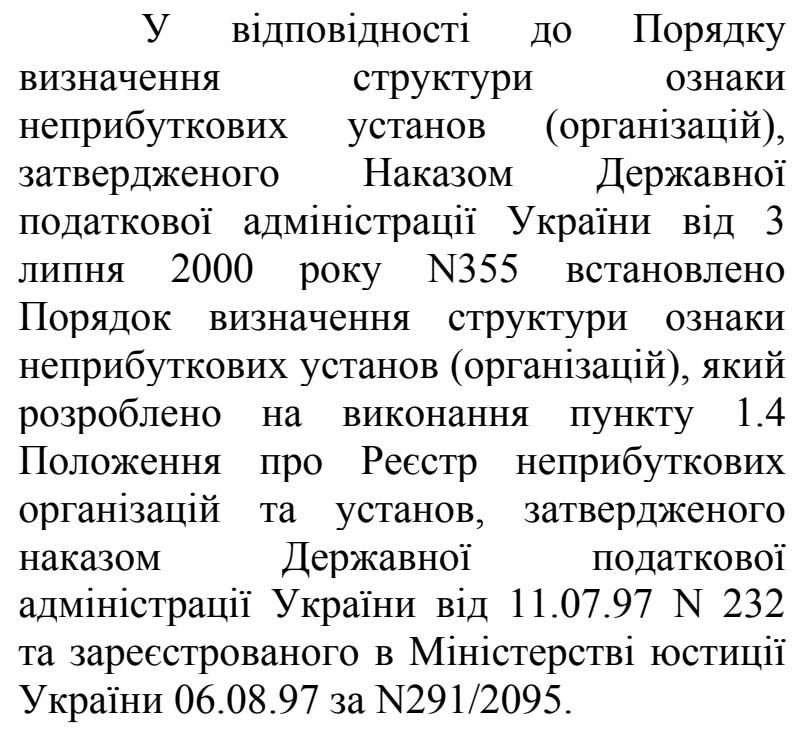

Визначення доходів та витрат неприбуткових організацій 3 метою оподаткування здійснюється на підставі ПБО та даних бухгалтерського обліку.

3 метою правильної організації облікових процесів, складання достовірної фінансової звітності та Звіту неприбутковій організації важливо в обліковій політиці передбачити оптимальну модель бухгалтерського обліку. При формуванні облікової політики варто враховувати Методичні рекомендації № 635 та організаційні особливості кожної конкретної неприбуткової організації.

Отже, всі неприбуткові організації (як підприємницького характеру, так і ті, що не мають заборони на підприємницьку діяльність) об'єднані одним принципом: доходи, отримані в межах своєї статутної діяльності, використовуються винятково для фінансування видатків на утримання такої організації, реалізації мети (цілей, завдань) та напрямів діяльності, визначених іiї статутними документами. Саме такий принцип передбачено пп. 133.4.2 п. 133.4 ст. 133 Податкового кодексу [1], і він суттєво впливає на побудову бухгалтерського обліку неприбуткових організацій.

На сьогодні законодавством передбачено два варіанти ведення бухгалтерського обліку:

$$
\text { повний аналітичний та }
$$

синтетичний облік з використанням Плану рахунків бухгалтерського обліку активів, капіталу, зобов'язань і господарських операцій підприємств;

- спрощена система обліку i звітності із застосуванням спрощеного Плану рахунків бухгалтерського обліку [8].

Слід зазначити, що законодавством не врегульовано можливість використання неприбутковою організацією спрощеної системи обліку та звітності. У зв'язку з цим організація обліку в неприбутковій організації має свої особливості (рис. 1).

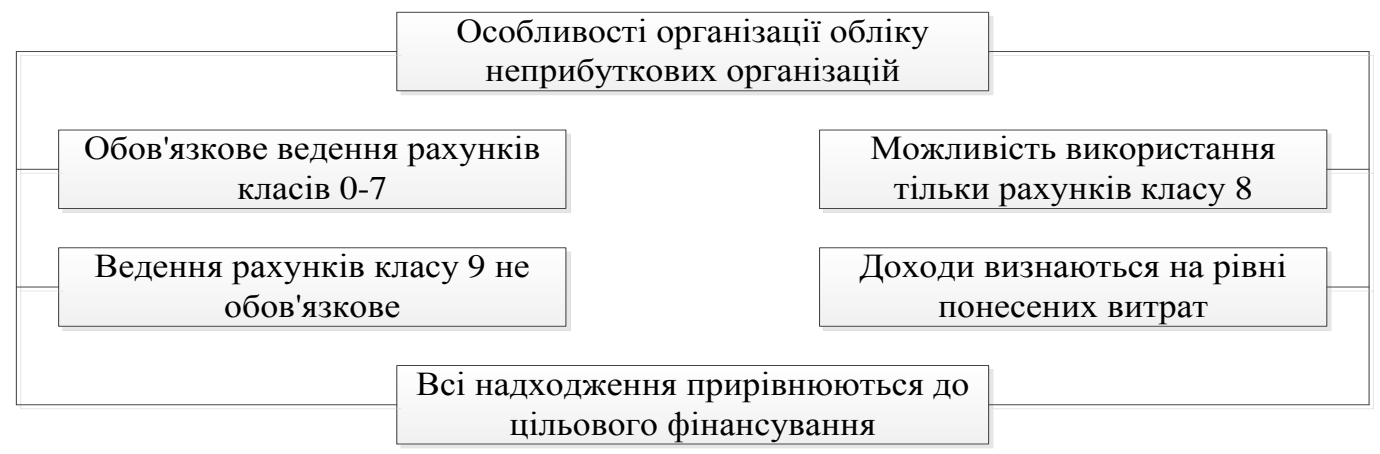

Рис. 1. Особливості організації обліку неприбуткової організації

3 огляду на специфіку діяльності неприбуткових організацій доцільно визнавати всі надходження таких організацій цільовим фінансуванням та цільовими надходженнями, включаючи орендні платежі, відсотки, отримані за депозитами, курсові різниці [8].

Порядок визнання і відображення витрат регламентований П(С)БО 16. Ніяких особливостей для неприбуткових 
організацій цей стандарт не містить. Загальні правила обліку витрат такі (п. 5-8 П(С)БО 16):

витрати відображаються одночасно зі зменшенням активів або збільшенням зобов'язань;

- витратами звітного періоду визнається таке збільшення активів або зменшення зобов'язань, яке приводить до зменшення власного капіталу, за умови, що ці витрати можуть бути достовірно оцінені;

- витрати визнаються витратами певного періоду одночасно 3 визнанням доходу, для отримання якого вони були здійснені;

- витрати, які неможливо прямо пов'язати 3 доходом певного періоду, відображаються в періоді їх здійснення.

При отриманні та освоєнні коштів цільового фінансування неприбуткові організації повинні орієнтуватися на норми п. 17-18 П(С)БО 15 і визнавати доходи «під витрати»; якщо актив забезпечує отримання економічних вигід протягом декількох звітних періодів, то витрати визнаються шляхом систематичного розподілу його вартості (наприклад, у вигляді амортизації) між такими звітними періодами. Усі витрати неприбуткової організації класифікуються залежно від характеру операцій і видів діяльності [9].

Аналіз

особливостей

бухгалтерського обліку неприбуткових організацій дозволив визначити основні проблеми, з якими вони стикаються під час реалізації власної діяльності:

- нестача кадрів, брак методичних посібників 3 ведення бухгалтерського обліку та складання фінансової звітності; відсутність спеціального програмного забезпечення для ведення бухгалтерського обліку в неприбуткових організаціях.

Для їх вирішення, на нашу думку, слід виконати наступні дії:

- підготувати на законодавчому рівні проекти, що спрощують надання річних звітів неприбуткових організацій;

- запровадити проекти надання консультаційної допомоги за нормативами ведення бухгалтерського обліку в неприбуткових організаціях;

- розробити єдині правила ведення бухгалтерського обліку та складання фінансової звітності в неприбуткових організаціях.

Висновки даного дослідження та перспективи подальших робіт у цьому напрямку. Неприбуткова організація - це самостійний суб'єкт господарювання за правами юридичної особи, який здійснює діяльність згідно установчих документів, має самостійний баланс, поточні рахунки в банках, печатку, веде бухгалтерський облік, подає звітність згідно із законодавством, не має на меті отримання прибутку. Визначення доходів та витрат неприбуткових організацій 3 метою оподаткування здійснюється на підставі ПБО та даних бухгалтерського обліку. Всі неприбуткові організації (як підприємницького характеру, так i ті, що не мають заборони на підприємницьку діяльність) об'єднані одним принципом: доходи, отримані в межах своєї статутної діяльності, використовуються винятково для фінансування видатків на утримання такої організації, реалізації мети (цілей, завдань) та напрямів діяльності, визначених їі статутними документами.

\section{ПЕРЕЛІК ВИКОРИСТАНИХ ДЖЕРЕЛ}

1 Податковий кодекс України [Електронний ресурс] // Відомості Верховної Ради України. - 2011. - №13-14, №15-16, №17. - Чинний станом на 01.03.2019. - Режим доступу: https://zakon.rada.gov.ua /laws/ show/2755-17

2 Закон України Про внесення змін до Податкового кодексу України щодо оподаткування неприбуткових організацій [Електронний ресурс] // Відомості Верховної Ради України. - 2015. - №42. Чинний станом на 13.08.2015. - Режим доступу: 
https://zakon.rada.gov.ua/laws/show/652-19

3 Слободяник Ю.Б. Некоммерческие организации в Украине: бухгалтерский учет, налогообложения и аудит [Электронный ресурс] / Ю.Б. Слободяник // Бухгалтерский учет в бюджетных и некоммерческих организациях. - 2013. №6. - - Режим доступа: https://wiseeconomist.ru/poleznoe /85788nekommercheskie-organizacii-ukrainebuxgalterskij-uchet-nalogooblozhenie-audit

4 Пантейлічук С.Л. Особливості обліку в неприбуткових організаціях [Електронний ресурс] / С.Л. Пантелійчук // Київський бухгалтер. - 2010. - №39. Режим http://cons.parus.ua/_d.asp?r=06

STP2336fc0d693791e3afdaa8ecfab0f426

5 Панченко, С.В. Підприємництво [Текст]: підручник / С.В. Панченко, В.Л. Дикань, О.В. Шраменко, О.М. Полякова, Ю.М. Уткіна. - Х.: УкрДУЗТ, 2016. - Ч.2. Реалізація підприємницької діяльності у сучасних ринкових умовах. $-241 \mathrm{c}$.

6 Панченко, С.В. Підприємництво [Текст]: підручник / С.В.Панченко, В.Л. Дикань, О.В. Шраменко, О.М. Полякова, Ю.М. Уткіна. - Х.: УкрДУЗТ, 2016. - Ч.1. Теоретичні основи організації підприємницької діяльності. $241 \mathrm{c}$.

7 Панченко. С.В. Управління бізнесом [Текст]: підручник / С.В. Панченко, В.Л. Дикань, I.В. Воловельська та ін.; за заг. ред. В.Л. Диканя. - Харків: УкрДУЗТ, 2017. - 288 с.

8 Габрук О., Пантелійчук Л. Звітність «неприбутковців» [Електронний pecypc] / О. Габрук, Л. Пантелійчук // Офіційно про податки: офіційне видання державної фіскальної служби України. 2018. - №4(956). - Режим доступу: http://www.visnuk.com.ua/uk/publication/1000 07026-zvitnist-nepributkivtsiv

9 Папінова О. Бухгалтерських облік у неприбуткових організаціях [Електронний pecypc] / О. Папінова // uteka: швидкий пошук надійних рішень i практичної інформації. - 2017. - Режим доступу: https://uteka.ua/ua/publication/commerce-12sxemy-buxgalterskix-provodok-30-buxgalt erskij-uchet-v-nepribylnyx-organizaciyax

10 Тарасова М. Налоговый учет в неприбыльных организациях [Электронный ресурс] / М. Тарасова // Дебет-кредит. 2013. - №21. - Режим доступа: https://online.dtkt.ua/Book/«ДК»\%20№212013\%20(pyc.).epub/navPoint-8

\section{REFERENCES}

1 Verxavna Rada Ukrayiny' (2011) Podatkovy`j kodeks Ukrayiny' [Tax code of Ukraine]. Vidomosti Verxovnoyi Rady Ukrayiny [Information Of The Verkhovna Rada Of Ukraine]. (electronic journal), no. 1314, 15-16, 17. Available at: https://zakon.rada.gov.ua/laws/show/2755-17 (accessed 15 January 2019).

2 Verxavna Rada Ukrayiny' (2015) Zakon Ukrayiny' Pro vnesennya zmin do Podatkovogo kodeksu Ukrayiny' shhodo opodatkuvannya nepry`butkovy`x organizacij [Law of Ukraine On amendments to the Tax code of Ukraine on taxation of non-profit organizations]. Vidomosti Verxovnoyi Rady Ukrayiny [Information Of The Verkhovna Rada Of Ukraine]. (electronic journal), no. 42. Available https://zakon.rada.gov.ua/laws/show/652-19 (accessed 16 January 2019).

3 Slobodyanik Yu. B. (2013) Nekommercheskie organizatsii $v$ Ukraine: bukhgalterskiy uchet, nalogooblozheniya $i$ audit [Non-profit organizations in Ukraine: accounting, taxation and audit]. Bukhgalterskiy uchet $v$ byudzhetnykh $i$ nekommercheskikh organizatsiyakh [Accounting in budget and non-profit organizations] (electronic journal), no. 6. Available at: https://wiseeconomist.ru/ poleznoe/85788-nekommercheskie-organizaciiukraine-buxgalterskij-uchet-nalogooblozhenieaudit (accessed 20 January 2019).

$$
4 \text { Pantejlichuk S. L. (2010) }
$$

Osobly'vosti obliku $v$ nepry'butkovy`x organizaciyax [Features of accounting in nonprofit organizations]. Ky yivs`ky`j buxgalter 
[Kyiv accountant]. (electronic journal), no. 39. Available at: http://cons.parus.ua/_d.asp?r=06 STP2336fc0d693791e3afdaa8ecfab0f426 (accessed 25 January 2019).

5 Panchenko S. V., Dy`kan` V. L., Shramenko O. V., Polyakova O. M., Utkina Yu. M. (2016) Teorety`chni osnovy` organizaciyi pidpry`yemny`cz koyi diyal’nosti [Theoretical bases of the organization of business activity]. Pidpry yemny 'cztvo [Business]. Xarkiv: UkrDUZT. (in Ukrainian)

6 Panchenko S. V., Dy`kan` V. L., Shramenko O. V., Polyakova O. M., Utkina Yu. M. (2016) Realizaciya pidpry`yemny`cz koyi diyal 'nosti u suchasny`x ry`nkovy`x umovax [Implementation of entrepreneurial activity in modern market conditions]. Pidpry yemny cztvo [Business]. Xarkiv: UkrDUZT. (in Ukrainian)

7 Panchenko S. V., Dy`kan` V. L., Volovel's`ka I. V. ta in. (2017) Upravlinnya biznesom [Business management]. Xarkiv: UkrDUZT. (in Ukrainian)

8 Gabruk O., Pantelijchuk L. (2018) Zvitnist «nepry 'butkovciv» [Reporting «nonprofit»]. Oficijno pro podatky: oficijne vy`dannya derzhavnoyi fiskal noyi sluzhby
Ukrayiny [Official report on taxes: official publication of the state fiscal service of Ukraine] (electronic journal), no. 4(956). Available at: http://www.visnuk.com.ua/uk/publication/1000 07026-zvitnist-nepributkivtsiv (accessed 30 January 2019).

9 Papinova O. (2017) Buxgalters ky`x oblik $u$ nepry`butkovy`x organizaciyax [Accounting in non-profit organizations]. Uteka: shvy`dky`j poshuk nadijny`x rishen' $i$ prakty chnoyi informaciyi [Uteka: quick search for reliable solutions and practical information]. (electronic journal). Available at: https://uteka.ua/ua/publication/commerce-12sxemy-buxgalterskix-provodok-30buxgalterskij-uchet- $v$-nepribylnyxorganizaciyax (accessed 27 January 2019).

10 Tarasova M. (2013) Nalogovyy uchet $v$ nepribyl'nykh organizatsiyakh [Tax accounting in non-profit organizations]. Debetkredit [Debit-credit] (electronic journal), no. 21. Available at: Rezhim dostupa: https://online.dtkt.ua/Book/«DK»\%20№212013\%20(rus.).epub/navPoint-8 (accessed 22 January 2019).

\title{
КОНТРОЛІНГ ЕКОНОМІЧНОЇ БЕЗПЕКИ ПІДПРИЕМСТВ ПОРТОВОЇ ДІЯЛЬНОСТІ
}

\author{
Онешко С.В., к.е.н., доцент, \\ Попов I.I., махістр (ОНМУ)
}

У статті розглянуті особливості побудови системи управління економічною безпекою підприємств портової діяльності та запропоновано підхід до оиінки рівня економічної безпеки на базі системи контролінгу, який включає оцінку станів: ринку, фінансів, матеріальних ресурсів, розрахунків та інновацій. Запропонований підхід трунтується на системі показників, які характеризують діяльність підприємств портової діяльності, включає аналіз відхилень фактичних показників від планових, виявлення причин відхилень та розробку корегувальних заходів.

Ключові слова: економічна безпека, контролінг, управління, ризики, підприємства портової діяльності

(C) Онешко C.В.,

Попов I.I.

Вісник економіки транспорту і промисловості № 65, 2019 